\title{
BIOEDUSCIENCE
}

\author{
ISSN: 2614-1558
}

http://journal.uhamka.ac.id/index.php/bioeduscience

\section{Effect of Free Inquiry Approach Based on Blended Learning to Student Communication Skills}

\author{
Ernawati1 $^{*}$, Tri Maniarta Sari ${ }^{1}$ \\ 1University of Sembilan belas November, Kolaka, Jl. Pemuda, Kabupaten Kolaka, Indonesia, 93561
}

*Correspondent Email: ernaern3012@gmail.com

Check for updates

\section{ARTICLE INFO}

Article history:

Received: 30 Aug 2021

Accepted: 24 Nov 2021

Published: 31 Dec 2021

\section{Keywords:}

Blended learning;

Communication skills;

Free inquiry approach;

Students;

\section{Kata kunci:}

Blended learning;

Keterampilan komunikasi;

Free inquiry approach;

Mahasiswa

\section{A B S T R A C T}

Background: Communication skills are 21st-century learning skills that need to be mastered by students of the Biology Education Study Program of the University of nineteen November Kolaka as prospective teachers to face increasingly complex challenges. The research aims to analyze students communication skills by applying a free inquiry approach based on blended learning. Method: Quasi Research Experiment with Non-equivalent Control Group Design design. Control groups use conventional models (online group discussions), while experimental groups apply a free inquiry approach based on blended learning. Student communication skills data is obtained through observation sheets and analyzed using inferential statistical analysis (t-test) with the help of IBM SPSS Statistic 20 with the formula Analyze-Compare Means-Independent T-Test and descriptive statistics by calculating the average score of each indicator of student communication skills. Results: Obtained a level of significance $(p<0.05)$ or $(4,335>2,056)$, then Ha was accepted and $\mathrm{H}_{0}$ was rejected, meaning there was an effect on the application of free inquiry approach based on blended learning to student communication skills. The results of the description analysis showed an average score of student communication skills in the experimental class of 74.24 with good categories and control classes of 60.39 with good categories. Conclusion: Learning by applying a free inquiry approach based on blended learning positively influences students communication skills.

Pengaruh Free Inquiry Approach Berbasis Blended Learning terhadap Keterampilan Komunikasi Mahasiswa

\section{A B S T R A K}

Background: Keterampilan komunikasi merupakan salah satu keterampilan belajar abad 21 yang perlu dikuasai oleh mahasiswa Prodi Pendidikan Biologi Universitas Sembilanbelas November Kolaka, sebagai calon guru untuk menghadapi tantangan yang semakin kompleks. Penelitian bertujuan untuk menganalisis keterampilan komunikasi mahasiswa melalui pembelajaran dengan menerapkan Free inquiry approach berbasis blended learning. Metode: Penelitian Quasi Eksperiment dengan desain Non-equivalent Control Group Design. Kelompok kontrol, perkuliahan dengan menerapkan model konvensional (diskusi kelompok secara online) sedangkan kelompok eksperimen menerapkan Free inquiry approach berbasis blended learning. Data keterampilan komunikasi mahasiswa diperoleh melalui lembar observasi, dan dianalisis menggunakan analisis statistik inferensial (uji t) dengan bantuan IBM SPSS Statisctic 20 dengan rumus Analyze-Compare Means-Independent T-Test dan statistik deskritif dengan menghitung rerata skor setiap indikator keterampilan komunikasi mahasiswa. Hasil: Diperoleh tingkat signifikansi ( $\mathrm{p}<$ $0,05)$ atau $(4,335>2,056)$ maka Ha diterima dan $\mathrm{H} 0$ ditolak, artinya ada pengaruh penerapan free inquiry approach berbasis blended learning terhadap keterampilan komunikasi mahasiswa, dan hasil analisis deskripsi menunjukkan skor rata-rata keterampilan komunikasi mahasiswa pada kelas eksperimen sebesar 74,24 dengan kategori baik dan pada kelas kontrol sebesar 60,39 dengan kategori cukup. Kesimpulan: Pembelajaran dengan menerapkan free inquiry approach berbasis blended learning memberikan pengaruh positif terhadap keterampilan komunikasi mahasiswa. 


\section{Introduction}

The role of educational institutions, including universities, plays an essential role in preparing human resources that can be adaptive to the demands of the industrial revolution era 4.0, namely by increasing the competence of graduates, who in addition to mastering science and technology by the field they are involved in, also have skills, according to the demands of the 21st century (Arnyana, 2019). The 21st-century era focuses more on specific specializations, so Indonesian national education goals should equip graduates with 21st-century skills (Ardianto \& Ernawati, 2021). The results of research conducted by more than 250 researchers from 60 world institutions who are members of ATC21S (Assessment \& Teaching of 21st Century Skills) classify 21st-century learning skills into four categories (known as 4C skills), namely: Communication, Collaboration, Critical Thinking and Problem, Creativity and Innovation (Arifin, 2017).

21st-century skills need to be integrated or designed in learning activities because they will significantly help students face the challenges of life both now and in the future, especially for students majoring in education who will later become educators who will implement and develop 21st-century learning skills their participants. Teach him (Ardianto \& Ernawati, 2021). Learning in the 21st century is different from learning in the past. In the past, learning was carried out without regard to standards, while now it requires standards to achieve learning objectives. Through the measures that have been set, the teacher has definite guidelines about what is taught and what is to be completed. Teachers and students, lecturers and students, educators and students must have teaching and learning skills in this 21st century. Several challenges and opportunities must be faced to survive in the knowledge age in this information age (Pratiwi et al., 2019).

Communication skills are one of the 21st-century learning skills. A person must be able to effectively analyze and process a large amount of communication in their lives today, which sources of information are accurate or not and how to use the data effectively. The power of communication is everywhere in this modern world, even in teaching, and communication skills are very important, while education today always emphasizes fluent reading, correct speech and good writing where the most basic things that students themselves have not mastered (Narayanti, 2017). Communication skills are skills that are needed in all aspects of life. Communication skills convey new thoughts, ideas, knowledge, and information to others through oral, written symbols, pictures, graphics, or numbers. These skills include listening skills, obtaining information, and conveying ideas in front of many people (Putri et al., 2016).
As prospective teachers, students of the biology education department at Sembilanbelas, November Kolaka University, are expected to master communication skills to face increasingly complex challenges and become educators who can prepare human resources who master 21stcentury skills. Communication skills are essential to support students' success in expressing their opinions and listening to opinions from others, expressing the results of thoughts, ideas, knowledge, or new information, both in writing and orally. Communication skills are an essential capital to carry out good social interactions. Moreover, these skills are not just possessed by students.

The preliminary research results from observations and interviews, learning at Sembilanbelas November Kolaka University, Biology Education department is currently not explicitly designed to train 21st-century skills, including communication skills. So that it has an impact in the form of the ability of students to communicate ideas/ideas that are not optimal, many students do not dare to express their opinions, have not been able to convey their questions or opinions properly, speak in a voice that is not clear and not understood, express the results of thoughts, ideas, or information both in writing and in writing. Orally unsystematic and difficult to understand, and they have not been able to access scientific information precisely and accurately. Thus, it is deemed necessary to carry out learning/lectures to train or improve students communication skills.

Improving the communication skills of Biology Education students at Sembilanbelas November Kolaka University through learning activities requires appropriate learning strategies or approaches at the tertiary level. The free inquiry approach based on blended learning can be applied by integrating 21st-century skills into it. The free inquiry approach based on blended learning is a learning approach that gives students the freedom to determine problems to investigate, find and solve problems independently (Mudalara, 2012). So that in this learning process, students learn more on their own, develop critical thinking, creativity in solving problems. This learning refers to learning that combines face-to-face learning and online learning (Blended Learning) so that it has the opportunity to provide more flexible time and student assignments. Students can more easily understand the material content because, during lectures with a free inquiry approach, media for discussion and sharing information is carried out in person (face-to-face) and online. Combining the free inquiry approach with Blended Learning can create practical and efficient meaningful learning. It is expected to improve $21^{\text {st-century skills more }}$ effectively, including student communication skills (Adi et al., 2017).

Free inquiry learning based on blended learning allows students to have independent and sustainable learning, 
train them to develop the ability to interact with others, work with others to solve problems and communicate the results of thoughts, ideas or information they find. Both directly (face to face) and through online media, blended learning is also an effective solution in changing according to current conditions (the Covid-19 pandemic).

Through research conducted by the author in 2021 with the title "Implementation of the Free Inquiry Approach Based on Blended Learning on 21 $1^{\text {st }}$ Century Learning Skills for Biology Education Students at Sembilanbelas November Kolaka University", one of the 21 st. Century learning skills that become a variable and analyzed by researchers is student communication skills, where this communication skill is considered very important to be mastered by students to be able to carry out social interactions well, especially in facing the increasingly complex challenges of the 21st century. Through lectures with the Free Inquiry Approach Based on Blended Learning, students communication skills can be trained and improved. The role of the lecturer is significant in directing students to introduce each dimension of communication, including by compiling reports on the results of activities, presentation of assignments, group/class discussions, online learning, and other activities that lead to various social interactions.

\section{Method}

Research that aims to analyze 21st-century learning skills (including student communication skills) through learning/lectures by applying the Free inquiry approach based on blended learning is Quasi-Experiment research which was carried out using the Non-equivalent Control Group Design.

\section{Scope of Research}

The population in this study were all students of the Biology Education Department, Sembilanbelas November Kolaka University for the Academic Year 2020/2021, totalling 130 people.

The sampling technique uses the Non-Probability Sampling method with the Purposive Sampling technique. The 4th-semester biology education students were selected as research samples divided into two groups, namely the experiment group and the control group. The experiment group was treated with a free inquiry approach based on blended learning, while the control group used a conventional approach (group discussion).

\section{Research Design}

This research was carried out using the Non-equivalent Control Group Design. Both the experiment and control groups are compared in this design, although these groups are selected and placed without going through random.
$\mathrm{A}=\mathrm{O}_{1}$

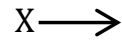
$\mathrm{O}_{2}$
$\mathrm{B}=\mathrm{O}_{1}$
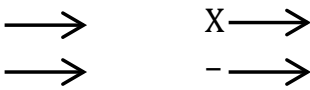
$\mathrm{O}_{2}$

Description:

A: Experiment Class

B: Control Class

X: Treatment/application of blended learning-based free inquiry approach

-: Conventional learning

01: Pre-Test

02: Post Test

\section{Research Procedure}

This research uses a control group and an experiment group. In the control group, lectures/learning of biology teaching and learning strategies were carried out by applying conventional models/methods (online group discussions), while in the experiment group, lectures/learning of biology teaching and learning strategies were carried out by applying the Free inquiry approach based on blended learning.

The instrument used to measure students communication skills in this study was a performance observation sheet that was compiled and used to assess students communication skills during lectures according to indicators consisting of two aspects of verbal (speaking, thinking, and writing) communication skills: speaking skills (verbal) with four indicators (skills in presenting the results of group work, asking questions, giving answers/opinions, and speaking in a clear voice), thinking skills with two indicators (skills in delivering answers/responses with solid evidence/references) support, and carry out discussions with group friends), writing skills with two indicators (writing the results of the discussion, and compiling a complete and easy-tounderstand report) and non-verbal (sign language) with three indicators (seeing the other person when communicating, pleasant facial expressions). Moreover, (uses supporting movements according to the conversation).

The instrument validity test in this study was carried out with content and construct validity. To determine the validity of the contents of the instrument in this study, a grid was prepared first, after which corrections were made to the items that had been made by consulting the research instrument to two experts who could provide input on the instruments that had been prepared. Furthermore, ten respondents in other classes tested the revised instrument for external validation. The data obtained were analyzed using the product-moment correlation formula from Pearson (Arikunto, 2006). The instrument validation test accepted that $r$ arithmetic was more significant than the $r$ table (0.66), which was in the range of $0.740-0.900$, so that the instrument used was declared valid. Furthermore, the reliability test obtained the value of $r(\alpha)=0.809$ with $r$ table $(0.60)$, so that the instrument is declared reliable.

\section{Data Collection and Data Analysis}

The data collection technique used in this study is data on student communication skills obtained through 
performance observation sheets and student presentations during lectures/learning researcher (Sunjaya et al., 2021).

Data on student communication skills were analyzed using inferential statistics and descriptive statistics. Inferential statistical analysis (t-test) was conducted to determine whether there was a difference between the two samples studied with a significance level of 0.05 . The calculation of the t-test in this study was carried out with the help of the IBM SPSS Statistics 20 program with the Analyze-Compare Means-Independent T-Test formula. Analysis of student communication skills used descriptive statistics by calculating the average score of each indicator from the data from the observation sheet using the formula:

$$
\bar{X}=\frac{\sum X}{n}
$$

Description:

$\mathrm{X}=$ Score/achievement of each communication skill indicator

$\sum X=$ Total score obtained by students

$\mathrm{n} \quad=$ Number of students

The score/ achievement of each communication skill indicator is then interpreted and categorized based on a scale of $0-100$, which is described in Table 1 (Arikunto, 2006).

Table 1. Category of Each Indicator of Student Communication Skills

\begin{tabular}{cc}
\hline Scale & Category \\
\hline $0-20$ & Very less \\
$21-40$ & Less \\
$41-60$ & Average \\
$61-80$ & Good \\
$81-100$ & Very good \\
\hline
\end{tabular}

\section{Result}

The results of inferential statistical analysis consisting of homogeneity test and t-test of student communication skills data between the control class and the experimental class are presented.

Tabel 2. Group statistics

\begin{tabular}{ccccc}
\hline Group & $\mathbf{N}$ & Mean & SD & Std. Error \\
\hline $\begin{array}{c}\text { Exsperimen } \\
\text { class }\end{array}$ & 14 & 73.5000 & 9.01921 & 2.41049 \\
Control class & 14 & 59.7857 & 7.66790 & 2.04933 \\
\hline
\end{tabular}

The results of the test of variance (homogeneity) between the control class and the experimental class obtained a significance value ( $p$ ) of 0.72 , which means $p>$ 0.05 so that it can be stated if the two classes have the same variance (homogeneous).

Tabel 3. Independent Samples Test

\begin{tabular}{ccccccc}
$\begin{array}{c}\text { Levene's } \\
\text { Test }\end{array}$ & \multicolumn{4}{c}{ t-test for Equality of Means } \\
\hline F & Sig. & t & df & Sig. & Mean & SD \\
\hline
\end{tabular}

\begin{tabular}{|c|c|c|c|c|c|c|c|}
\hline $\begin{array}{l}\text { Equal } \\
\text { variances } \\
\text { assumed }\end{array}$ & .131 & .720 & 4.335 & 26 & .000 & $\begin{array}{c}13.7142 \\
9\end{array}$ & 3.16389 \\
\hline $\begin{array}{l}\text { Equal } \\
\text { variances } \\
\text { not } \\
\text { assumed }\end{array}$ & & & 4.335 & $\begin{array}{c}25.34 \\
4\end{array}$ & .000 & $\begin{array}{c}13.7142 \\
9\end{array}$ & 3.16389 \\
\hline
\end{tabular}

Furthermore, the average difference test (Independent Sample t-test) with the criteria used in the test is stated using the $\mathrm{HO}$ and $\mathrm{Ha}$ hypotheses. $\left(\mathrm{H}_{0}\right.$ : there is no effect of the implementation of the free inquiry approach based on blended learning on students communication skills and Ha: there is an effect of implementing the free inquiry approach based on blended learning on students communication skills) obtained a significance level (p) of 0.00 , which is smaller than $0.05(\mathrm{p}<0.05)$ or the t-test is more significant than $\mathrm{t}$ table $(4.335>2.056)$. $\mathrm{Ha}$ is accepted, and $\mathrm{H}_{0}$ is rejected, meaning that applying the free inquiry approach based on blended learning on students' communication skills is an effect.

The results of the data analysis of student communication skills consisting of 11 indicators both through recovery by applying a free inquiry approach based on blended learning (experiment class) or through conventional learning models (control class) are described as follows.

\section{Speaking Skills}

The results of students speaking skills between the experiment class and the control class are presented in Table 4.

Table 4. Results of Students Speaking Skills in Experiment Class and Control Class

\begin{tabular}{|c|c|c|c|c|}
\hline \multirow{2}{*}{$\begin{array}{l}\text { Speaking Skill } \\
\text { Indicator }\end{array}$} & \multicolumn{2}{|c|}{ Experiment Class } & \multicolumn{2}{|c|}{ Control Class } \\
\hline & $(\%)$ & Category & $(\%)$ & Category \\
\hline $\begin{array}{l}\text { Presenting the } \\
\text { results of } \\
\text { group work }\end{array}$ & 80,95 & $\begin{array}{l}\text { Very } \\
\text { good }\end{array}$ & 76,19 & Good \\
\hline $\begin{array}{l}\text { Asking } \\
\text { question }\end{array}$ & 76,19 & Good & 64,29 & Good \\
\hline $\begin{array}{l}\text { Give answers/ } \\
\text { opinions }\end{array}$ & 69,05 & Good & 52,38 & Average \\
\hline $\begin{array}{l}\text { Speak in a clear } \\
\text { voice }\end{array}$ & 83,33 & $\begin{array}{l}\text { Very } \\
\text { good }\end{array}$ & 71,43 & Good \\
\hline Total & 77,38 & Good & 66,07 & Good \\
\hline
\end{tabular}

The results of speaking skills are: the indicator of the ability to present the results of group work in the experiment class obtained a score of $80.95 \%$ in the excellent category (Table 4). It was $76.19 \%$ in the control class in the excellent category. The ability to ask questions in the experiment class is $76.19 \%$ in the excellent category and $64.29 \%$ in the excellent category in the control class. Furthermore, the indicator of the ability to provide answers/opinions in the experiment class was $69.05 \%$ in the excellent category, and in the control class, it was 
$52.38 \%$ in the excellent category. The indicator of speaking ability with audible voice is $83.33 \%$, with an outstanding category in the experiment class and $71.43 \%$ with a suitable category in the control class. Meanwhile, the average score of speaking skills in the experiment class was 77.38 in the excellent category and 66.07 in the excellent category in the control class.

\section{Thinking Skills}

The results of students thinking skills between the experiment and control classes are presented in Table 5.

Table 5. Results of Students Thinking Skills in Experiment Class and Control Class

\begin{tabular}{lcccc}
\hline \multirow{2}{*}{ Thinking Skills } & \multicolumn{2}{c}{ Experiment Class } & \multicolumn{2}{c}{ Control Class } \\
\cline { 2 - 5 } & $\mathbf{( \% )}$ & Category & (\%) & Category \\
\hline $\begin{array}{l}\text { Submitting } \\
\text { answers/respon }\end{array}$ & & & & \\
$\begin{array}{l}\text { ses with strong } \\
\text { evidence/suppor } \\
\text { ting references }\end{array}$ & 71,43 & Good & 50,0 & Average \\
$\begin{array}{l}\text { Have a } \\
\text { discussion with a } \\
\text { group of friends } \\
\quad \text { Total }\end{array}$ & 59,52 & Average & 45,24 & Average \\
\hline
\end{tabular}

Based on Table 5, the students thinking skills show that the ability to convey answers or responses with strong evidence/supporting references in the experiment class obtained a score of $71.43 \%$ in the good category. In contrast, it was $50.0 \%$ in the control class with the good category. The indicator of the ability to carry out discussions with group friends in the experiment class is $59.52 \%$ and $45.24 \%$ in the control class, and each category is sufficient. Furthermore, the average score of thinking skills in the experiment class is 65.48 in the good category and 47.62 in the good category in the control class.

\section{Writing Skills}

The results of students writing skills between the experiment and control classes are presented in Table 6.

Table 6. Results of Students Writing Skills in Experiment Class and Control Class

\begin{tabular}{lcccc}
\hline \multicolumn{1}{c}{$\begin{array}{c}\text { Writing } \\
\text { Skills }\end{array}$} & \multicolumn{2}{c}{$\begin{array}{c}\text { Experiment Class } \\
\text { (\%) }\end{array}$} & Category & \multicolumn{2}{c}{ Control Class } \\
(\%) & Category \\
\hline $\begin{array}{l}\text { Write the } \\
\text { results of the } \\
\text { discussion }\end{array}$ & 76,19 & Good & 50,0 & Average \\
$\begin{array}{l}\text { Compile a } \\
\text { complete and } \\
\text { easy-to- } \\
\text { understand } \\
\text { report }\end{array}$ & 92,86 & Very good & 78,57 & Good \\
\hline \multicolumn{1}{c}{ Total } & 84,53 & Very good & 64,29 & Good \\
\hline
\end{tabular}

Based on Table 6, they showed the students' writing skills on the indicators of writing ability in the discussion results in the experiment class. A score of $76.19 \%$ was obtained in the good category, while in the control class, it was $50.0 \%$ in the excellent category. The indicator of composing a complete and easy-to-understand report in the experiment class was $92.86 \%$ in the outstanding category. The class was $78.57 \%$ in the excellent category. Furthermore, the average score of writing skills in the experiment class was 84.53 in the perfect category, and the control class was 64.29 in the excellent category.

\section{Non-Verbal Skills}

The results of students non-verbal skills (sign language) between the experiment class and the control class are presented in Table 7.

Table 7. Results of Non-Verbal Skills of Students in Experiment Class and Control Class

\begin{tabular}{|c|c|c|c|c|}
\hline \multirow{2}{*}{ Non-Verbal Skills } & \multicolumn{2}{|c|}{ Experiment Class } & \multicolumn{2}{|c|}{ Control Class } \\
\hline & $(\%)$ & Category & $(\%)$ & Category \\
\hline $\begin{array}{l}\text { Seeing the other } \\
\text { person when } \\
\text { communicating }\end{array}$ & 71,43 & Good & 54,76 & Average \\
\hline $\begin{array}{l}\text { Fun facial } \\
\text { expressions }\end{array}$ & 76,19 & Good & 71,43 & Good \\
\hline $\begin{array}{l}\text { Use supporting } \\
\text { movements } \\
\text { according to the } \\
\text { conversation }\end{array}$ & 59,52 & Average & 50,0 & Average \\
\hline Total & 69,05 & Good & 58,73 & Average \\
\hline
\end{tabular}

Based on Table 7 above, the students' non-verbal skills show that the skill of seeing the interlocutor when speaking in the experiment class obtained a score of $71.43 \%$ in the good category, while in the control class, it was $54.76 \%$ with the excellent category. The ability to show pleasant facial expressions in the experiment class is $76.19 \%$ in the excellent category, and the control class is $71.43 \%$ in the good category. The ability to use supporting movements is $59.52 \%$ and the control of $50.0 \%$ each in the excellent category. While the average score of non-verbal skills of students in the experiment class was 69.05, with an outstanding category, and in the control class was 58.73, with a good category.

Furthermore, from the overall indicators of student communication skills observed both in the experiment class and in the control class, the average score of student communication skills in the experiment class was 74.24 with good category and 60.39 in the control class with good category.

\section{Discussion}

Analysis of communication skills of students of the Biology Education Department Sembilanbelas November Kolaka University as one of the four learning skills of the 21st century (4C) through learning activities/lectures by applying a free inquiry approach based on blended learning is one of the efforts to prepare human resources, especially 
as prospective educators who master 21st-century skills. Using the free inquiry approach based on blended learning in lectures/learning will give students the freedom to determine problems to investigate, find and solve problems independently, collaborate and communicate with friends in solving problems both face-to-face and online.

Through the free inquiry approach learning stages, students get direct experience constructing their already knowledge. In this learning, students are encouraged to be actively involved in finding as much information as possible through research so that learning becomes meaningful, they discover and can create new things. The results of Shih et al., (2010) conclude that there is an influence of the blended learning model on students' ability. However, in the stages of free inquiry learning activities, of course, it requires knowledge, in-depth understanding of the material and more time so that the combination of online and face-to-face learning (blended learning) will provide adequate space and time for students to conduct the free inquiry. Thus, the application of the free inquiry approach based on blended learning in this study will improve and develop students communication skills (Prasetyorini et al., 2017; Shofiyah, 2017; Ramang, 2019).

Based on the results of statistical analysis of the average difference test (Independent Sample t-test) obtained a significance level (p) of 0.00 which is smaller than $0.05(\mathrm{p}<$ $0.05)$, or the $t$-count value is more significant than $t$ table $(4.335>2.056)$ which means that there is an effect of applying the free inquiry approach based on blended learning on students communication skills.

The results showed that students communication skills in the experimental class (learning by applying the free inquiry approach based on blended learning) were better than the control class (learning by using the conventional method, namely the group discussion method). In general, the indicators of speaking skills, the average score achieved in the experimental class is 77.38 in the good category and in the control class is 66.07 in the good category. For indicators of thinking skills, the average score in the experimental class is 65.48 in the good category and 47.62 in the control class with the good category. Furthermore, the average score of writing skills in the experimental class is 84.53 in the very good category, and the control class is 64.29 in the good category. For non-verbal skills (sign language) indicators, the average score of students in the experimental class is 690.05 in the excellent category and the control class 58.73 in the excellent category. Moreover, from the overall indicators of student communication skills observed, the average score of student communication skills in the experimental class was 74.24 with a suitable category and 60.39 in the control class with a good category.

The results showed that students communication skills in the experimental class (learning by applying the free inquiry approach based on blended learning) were better than the control class (learning by using the conventional method, namely the group discussion method). For the general speaking skills indicators, the average score achieved in the experimental class is 77.38 in the good category, and the control class is 66.07 in the good category. Furthermore, the experimental class's average writing skills score is 84.53 in the excellent category, and the control class is 64.29 in the good category. For nonverbal skills (sign language) indicators, the average score of students in the experimental class is 690.05 in the excellent category and 58.73 in the control class with the good category. Furthermore, from the overall indicators of student communication skills observed, the average score of student communication skills in the experimental class was 74.24 in the good category and 60.39 in the excellent category in the control class.

Thus, these results indicate that learning or lectures by applying the free inquiry approach based on blended learning positively influence students communication skills. Communication skills are one of the most critical 21st-century learning skills because these skills are skills needed in all aspects of life, skills required to interact with other people. This is in line with the opinion of Lunenburg (2010) and Redhana (2019) which state that 21st-century skills that are equally important are communication skills. Someone who has good communication skills can convey his ideas to others. This communication skill ranks first among all existing soft skills in soft skills. Meanwhile, Robles (2012) and Redhana (2019) states that integrity and communication are the two most critical soft skills workers need to succeed (Redhana, 2019).

During learning with the free inquiry approach based on blended learning, students are allowed to access and collect as much information as possible precisely and accurately, directed to communicate the ideas, ideas, knowledge and information they find to their group mates and other groups. They must dare to express their opinions and be guided to convey their questions or statements in clear and easy-to-understand language. Students are also asked to systematically and clearly express the results of their thoughts, ideas, or information in writing and orally systematically and clearly. During learning, students will be trained to communicate more effectively because their time and assignments are more flexible (blended learning), they can access material/information and communicate with their group friends anytime and anywhere through various online communication media, discussing and sharing information can also carried out directly (face to face) so that it will be more meaningful, more effective and efficient (Kirna et al., 2015; Aji, 2019; Sipayung et al., 2019).

Free inquiry learning based on blended learning can be designed by training some communication skills of students or students both verbally and non-verbally, where 
at each stage of learning, namely: orientation, formulating problems, proposing hypotheses, collecting data, and formulating conclusions which are carried out by combining online and face-to-face learning, students or students will practice expressing their ideas, ideas, or opinions both orally and in writing, they will access and exchange some information with their friends, discuss directly or online. The free inquiry approach based on blended learning will improve students' communication skills.

The results of this study are also in line with the results of Lewa (2017), where the application of the inquiry learning model has a positive effect on the communication skills of junior high school students with an influence rate of $12.75 \%$. Communication skills include conveying thoughts clearly and persuasively orally and in writing, the ability to express opinions in clear sentences, convey orders clearly, and motivate others through the ability to speak. Communication skills can be improved and developed through appropriate learning methods or models (Lewa, 2017).

Good communication skills are invaluable skills in work and everyday life. They are communicating means the development of speech and language that has emotional and social content, namely how the communication session can take place reciprocally (Septikasari \& Frasandy, 2018). Communication is an activity that is very often carried out by everyone in any scope, anywhere, and anytime. Communication brings together the communicant with the communicator. Communicants who receive while communicators deliver messages. Interacting by means of communication does not have to be with words but can also use gestures such as smiling, winking, waving, and using feelings in one heart. But the communication message will be accepted by the communicant if the communicant understands what the communicator is conveying (Septikasari \& Frasandy, 2018). To help students communicate effectively, of course, teachers or lecturers must train and familiarize their students to master communication skills. Developing these skills requires a planned and systematic effort, which must be done intentionally by making designs that are right on target. Conditioning learning so that these communication skills can be trained and a free inquiry approach based on blended learning can be an alternative to develop students communication skills.

The results of this study are also in line with the results of Adi et al. (2017), that Free inquiry learning which combines face-to-face learning and online learning can create independent, interactive, meaningful learning and can be used as a medium for discussion, asking questions, providing feedback, information sharing, and evaluation. This study has the opportunity to provide students with more flexible time and assignments. Blended learning optimizes free inquiry learning, where through online learning, students are more flexible in accessing and processing information, communicating, and collaborating in completing assigned tasks. Direct interaction through face-to-face learning will provide reinforcement and confirmation so that each stage of free inquiry learning will be more meaningful and optimal to improve 21st-century learning skills that students must master. (Zubaidah, 2016).

The implementation of the free inquiry approach based on blended learning has a good influence on the communication skills of Biology Education students, Sembilanbelas November Kolaka University. However, based on descriptive analysis, student communication skills can still be maximized. The average score of student communication skills is still in the excellent category. However, some students achieve perfect scores for some skill indicators. This is because allocating research time (implementing a free inquiry approach based on blended learning) is still insufficient to train and develop 21stcentury student learning skills. For this reason, in the lecture process, it is better to allocate as much time as possible when applying the free inquiry approach based on blended learning so that it can be maximized in developing and improving students 21st-century learning skills (Sweca, 2012; Susanti \& Arista, 2019; Sugiarti \& Dwikoranto, 2021; Sunjaya et al., 2021).

\section{Conclusion}

The results showed that the student's communication skills in the experimental class were better than in the control class, consisting of speaking, thinking, writing, and non-verbal skills. From the overall indicators of student communication skills observed, the average score in the experimental class was 74.24 in the excellent category. The control class was 60.39 , with the excellent category. Thus, it can be concluded that the application of the free inquiry blended learning-based approach in learning/lectures has a good (positive) influence on students communication skills. However, in this study, the variable of 21st-century learning skills that is measured is only student communication skills. At the same time, other 21st-century learning skills can also be studied by applying a blended learning-based free inquiry approach which is thought to be appropriate for the current lecture process, namely in the new average period-Post Covid-19 pandemic to the future.

\section{Acknowledgement}

The author would like to thank the Directorate of Resources, Directorate General of Higher Education, Ministry of Education, Culture, Research and Technology for funding this research through the 2021 PDP scheme.

\section{Declaration statement}

The authors reported no potential conflict of interest. 


\section{References}

Adi, W. C., Suwono, H., \& Suarsini, E. (2017). Pengaruh Guided Inquiry - Blended Learning. Jurnal Pendidikan: Teori, Penelitian, Dan Pengembangan, 2(10), 13691376.

Aji, M. Q. W. (2019). Mengembangkan Kecakapan Abad 21 Mahasiswa Melalui Model Pembelajaran Inkuiri. Teknodika, 17(2), https://doi.org/10.20961/teknodika.v17i2.35281

Ardianto, \& Ernawati. (2021). Implementasi Pendidikan Abad 21 Melalui Scientific Approach Di Sma Negeri 7 Bulukumba. PeTeKa (Jurnal Penelitian Tindakan Kelas Dan Pengembangan Pembelajaran), 4(1), 14-22. https://doi.org/10.31604/ptk.v4i1

Arifin, Z. (2017). Mengembangkan Instrumen Pengukur Critical Thinking Skills Siswa pada Pembelajaran Matematika Abad 21. Jurnal THEOREMS (The Original Research of Mathematics), 1(2), 92-100.

Arikunto, S. (2006). Prosedur Penelitian Suatu Pendekatan Praktik. PT. Rineka Cipta.

Arnyana, I. B. P. (2019). Pembelajaran Untuk Meningkatkan Kompetensi 4c(Communication, Collaboration, Critical Thinking Dancreative Thinking) Untuk Menyongsong Era Abad 21. Prosiding: Konferensi Nasional Matematika Dan IPA Universitas PGRI Banyuwangi, 113.

Kirna, I. M., Sudria, I. B. N., \& Tegeh, I. M. (2015). Apa Respons Dan Harapan Siswa Sma Tentang Blended Learning? Jurnal Pendidikan Dan Pengajaran, 48(1-3), 15-25. https://doi.org/10.23887/jppundiksha.v48i13.6914

Lewa, I. W. L. (2017). Implementasi Model Pembelajaran Inkuiri Terbimbing Pada Kemampuan Pemecahan Masalah Fisika Dan Kemampuan Komunikasi Siswa SMP. In Seminar Nasional Mipa 2006. Universitas Negeri Semarang.

Lunenburg, F. C. (2010). Communication: The Process, Barriers , And Improving Effectiveness. Schooling, 1, 1-11.

Mudalara, I. P. (2012). Pengaruh Model Pembelajaran Inkuiri Bebas Terhadap Hasil Belajar Kimia Siswa Kelas Xi Ipa Oleh I Putu Mudalara Program Studi Pendidikan Ipa Program Pascasarjana Universitas Pendidikan Ganesha. Universitas Pendidikan Ganesha.

Narayanti, P. S. (2017). Penegmbangan Workbook Pada Tema Sistem Transportasi Untuk Meningkatkan Keterampilan Berfikir Kritis Dan Penguasaan Konsep Siswa SMP. Universitas Pendidikan Indonesia.

Prasetyorini, H., . M., \& Bachri, B. S. (2017). Pengembangan Materi Pada Mata Pelajaran IPA Dalam Platform Course Networking Sebagai Media Pembelajaran Secara Blended Learning Untuk Meningkatkan Hasil
Belajar Dan Keterampilan Kolaborasi Peserta Didik Kelas VII SMP. Jurnal Pendidikan (Teori Dan Praktik), 1(1), 50. https://doi.org/10.26740/jp.v1n1.p50-58

Pratiwi, S. N., Cari, C., \& Aminah, N. S. (2019). Pembelajaran IPA Abad 21 dengan Literasi Sains Siswa. Jurnal Materi Dan Pembelajaran Fisika (JMPF), 9(1), 34-42.

Putri, A., Enawaty, E., \& Lestari, I. (2016). Deskripsi keterampilan komunikasi siswa sma negeri 9 pontianak melalui metode praktikum pada materi ksp. Jurnal Pendidikan Dan Pembelajaran IPA, 5(9), 1-11.

Ramang. (2019). Efektivitas Dan Efisiensi Pembelajaran Berbasis Blended Learning Di Madrasah Tsanawiyah Negeri Model Palu. Paedagogia: Jurnal Pendidikan, 7(2), 1-22. https://doi.org/10.24239/pdg.vol7.iss2.16

Redhana, I. W. (2019). 2239 Mengembangkan Keterampilan Abad Ke-21 Dalam. Jurnal Inovasi Pendidikan Kimia, 13(1), $2239-2253$.

Robles, M. M. (2012). Executive Perceptions of the Top 10 Soft Skills Needed in Today's Workplace. Business Communication Quarterly, 75(4), 453-465. https://doi.org/10.1177/1080569912460400

Septikasari, R., \& Frasandy, R. N. (2018). Keterampilan 4c Abad 21 Dalam Pembelajaran Pendidikan Dasar. Jurnal Tarbiyah Al-Awlad, 8(2), 112-122. https://doi.org/10.1016/j.jacc.2020.04.015

Shih, J. L., Chuang, C. W., \& Hwang, G. J. (2010). An inquirybased mobile learning approach to enhancing social science learning effectiveness. Educational Technology and Society, 13(4), 50-62.

Shofiyah, N. (2017). Penerapan Model Pembelajaran Modified Free Inquiry untuk Mereduksi Miskonsepsi Mahasiswa pada Materi Fluida. SEJ (Science Education Journal), 1(1), 19-28. https://doi.org/10.21070/sej.v1i1.836

Sipayung, H. D., Rahmatsyah, Sani, R. A., Bunawan, W., \& Lubis, R. H. (2019). Pengaruh Model Pembelajaran Collaborative Inquiry Terhadap Keterampilan 4C Siswa di SMA. Jurnal Pendidikan Fisika, 8(1), 29-38.

Sugiarti, M. I., \& Dwikoranto. (2021). Peningkatan Kemampuan Berpikir Kritis Peserta Didik Melalui Pembelajaran Blended Inquiry Learning Berbantuan Schoology Pada Pembelajaran Fisika: Literature Review. QUANTUM: Jurnal Inovasi Pendidikan Sains, 12(1), 49-62.

Sunjaya, D. K., Herawati, D. M. D., Indraswari, N., Megawati, G., \& Sumintono, B. (2021). Training and Assessing Model for the Ability of Community Health Volunteers in Anthropometric Measurement Using the Rasch Stacking and Racking Analyses. Journal of Environmental and Public Health, 2021. https://doi.org/10.1155/2021/5515712

Susanti, E., \& Arista, A. (2019). Analisa Tingkat Pengetahuan Guru terhadap Kompetensi 4C. Prosiding 
Seminar Nasional Ilmu Sosial Dan Teknologi (SNISTEK), September, 73-78.

Sweca, I. (2012). Pengaruh Model Pembelajaran Inkuiri Bebas Terhadap Penguasaan Materi Dan Kinerja Ilmiah Siswa Kelas X Sma Negeri 4 Denpasar. Jurnal Pendidikan Dan Pembelajaran IPA Indonesia, 2(1), 120.

Zubaidah, S. (2016). Keterampilan Abad Ke-21: Keterampilan Yang Diajarkan Melalui Pembelajaran. Seminar Nasional Pendidikan, 2, 1-17. 